\title{
Comment on Prazauskas, Tishkov, and Yamskov
}

\section{ZVI GITELMAN}

University of Michigan

Three important myths about Soviet nationality policy have been exploded since 1988. Most Soviet scholars and Western scholars admit that, contrary to Marxist-Leninist postulates, ethnic consciousness does not necessarily decline as society moves toward modernization or "socialism." In recent years in the U.S.S.R. ethnic consciousness has greatly expanded or surfaced. Second, the assertion that "druzhba narodov" (friendship of the peoples) is characteristic of Soviet society is belied by the death of over a thousand people in inter-ethnic clashes, the wounding of more than 8,000 , and the displacement of about a half-million others as a result of clashes in the Caucasus and Central Asia. The third myth is that of an "unshakeable union of free republics," exploded by declarations of sovereignty and independence by almost all republics. Soviet analysts and even politicians have had to admit that the cliches about the Soviet multiethnic society being of a "wholly different kind" and the emergence of a "Soviet nation" were exercises in self-deception and propaganda. As is so often the case in the age of glasnost', past falsifications are overcompensated for by sometimes excessive breast-beating and self-criticism. Thus, the articles by Prazauskas, Tishkov, and Yamskov are to be welcomed for their critical but balanced assessments and for their attention to the facts.

Dr. Prazauskas's article is an attempt to generalize from Soviet experience in order to make broader statements about ethnopolitics. However, it is not tested against enough cases, and it closely follows, in abstract and general terms, the specifics of Soviet experience. Like Dr. Tishkov, Prazauskas sees the solution to ethnic problems in democracy and a rejection of authoritarianism. Although it is hard to argue with that, we need to remember that democracies such as Canada, Belgium, Israel, and the United States have not "solved" the ethnic "problem," though they have been relatively successful in managing it so that their 
states have not disintegrated. Where Prazauskas and Tishkov differ is that the former believes that the Soviet Union contains many significantly different political cultures and that therefore it is very difficult to establish compatible patterns of behavior and rules of the game among the different political cultures, which overlap to a considerable extent with ethnic cultures.

Tishkov is much more sanguine about the compatibility of ethnic cultures, and stresses the potential for developing new political institutions that will allow different peoples to express themselves. He sees nationalist expression as a substitute for unfettered political life, the implication being that once the latter is achieved the former will no longer be necessary. By contrast, Prazauskas explicitly rejects "The attempt to establish individual equality" at the basis of "civil society" as a solution to nationality problems because, as he sees it, this merely separates individuals from their national groups. In effect, this is nothing but "the assimilation of minorities by the dominant ethnic group that serves as an integrative core." This would only exacerbate, not solve, the crisis of the nationalities.

Prazauskas probably exaggerates the degree of difference in the political cultures of the nationalities, and his claim that in 70 years the political cultures of the Slavic peoples and the "peripheral nationalities" have not drawn closer together needs empirical support. Moreover, it is not clear that the pre-Soviet political cultures of the Baltic peoples, Moldavians, Ukrainians, Central Asians, or peoples of the Caucasus were any less authoritarian than those of the Slavs. Prazauskas argues that local interethnic conflicts actually serve the interests of the anti-reformist bureaucracy because they allow the imposition of selective authoritarianism. Ulitmately, he agrees with Tishkov that the only guarantor of regulating interethnic conflicts is democracy, but he states that a democratic Russia is crucial.

Tishkov, on the other hand, hints that Russia herself suffered from the policies of preference "for previously backward peoples" and that the lack of political democracy, not Russian oppression, is the cause of the nationalities' troubles. Tishkov rejects self-determination of nations as a practical solution because the nations of the U.S.S.R. are so intermingled with each other that self-determination might well lead to the tyranny of national majorities. He shifts the focus from nations to the individual and, unlike Prazauskas, advocates the maintenance of the Soviet Union, which he sees as being in accord with European tenden- 
cies to inter-national integration. Tishkov advocates the abolition of individual national identification and any discrimination based on nationality. Clearly, this would lead many people to drop their national identification and hope to be associated with other nationalities. For example, Ukrainians living in Russia or Jews living in Ukraine might well choose to lose their ethnic identities. And yet, Tishkov suggests that cultural autonomy for the nationalities be broadened and new sovereign state units be permitted to form. There is no contradiction here if one assumes that the basic principle is individual choice: those who wish would be able to lose their national identities, whereas those who wish to strengthen those identities and cultures would be able to do so in both the cultural and political arenas. Tishkov's argument is a challenge to the advocates of non-Russian national causes: let us put the nationalists' claims to the test by giving individuals democracy and the right to assign their freely chosen priority to their national identifications.

A. N. Yamskov's study of the Armenian-Azerbaijani conflict alerts the Western reader to dimensions not usually mentioned in the secondary literature, notably the demographic and economic. These seem to explain more than historical or religious considerations. Yamskov's study is a fine example of how valuable Soviet analyses can be when freed of ideologically determined dogmas and shibboleths.

Not surprisingly, there is no consensus among the authors on a formula for the solution of the Soviet Union's current problems in relation to nationalities. This is as it should be, because no magic formula exists. The best any multi-ethnic state can do is to manage, not "solve," ethnic issues. It should construct a system to accommodate, not deny or suppress, ethnopolitics, and it should institutionalize consensual mechanisms for resolving disputes. Secondly, the state should provide for equal individual and collective rights, monitor their implementation, and try as best it can to be evenhanded in that implementation - and be perceived as such. Thirdly, the state should educate its citizens to attitudes such as mutual respect, tolerance, and appreciation of cultural diversity. One of the negative lessons learned from the Soviet experience is that the state should not attempt to define ethnic groups and assign membership to them, nor should the state consistently favor one group over another.

All of these are difficult to achieve, particularly when over seven decades bad habits were learned. Tishkov's advocacy of democratiza- 
tion is well taken and is a great enough challenge for the Soviet Union. It is doubtful whether it is sufficient to "solve" the nationalities problem, because many people will not be satisfied with individual rights but will press for the achievement of their group as well. Democracy will not make ethnopolitics disappear, but it could make it manageable. 